p. 348); "On Certain Early Malformations of the Embryo" (ibid., p. 436); "On some Conditions related to Double Monstrosity" (ibid., vol. xviii., p. 25); "The Effects of Electricity and Magnetism on Development" (ibid., vol. xxix., p. 346); "On the Myology of Dolichotis Patagonica and Dasyprocta Isthmica" (ibid., vol. xxxi., p. 343); "On some Points in Comparative Myological Nomenclature" (ibid., vol. xxxi., p. 522); "On the Anatomy of Macropus Rufus" (ibid., vol. xxxii., p. I19); "On a Specimen of Bifid Clitoris" (Proc. Anat. Soc. Gt. Brit., I893, vol. xxii.); "On the Cusps of the Aortic Pulmonary Orifices" (ibid., I895, vol. iv.); "On the Double Malformations amongst Fishes" (Proc. Zool. Soc., I895, p. 423); "On the Myology of the Terrestrial Carnivora. Part I., Muscles of the Head, Neck and Fore-Limb" (ibid., I897, p. 370); "On the Physical Characters of the Boys at King Edward's Schools, Birmingham, and at certain other Public Schools" (Proc. Birm. Phil. Soc., 1892, 216); "On the Physical Characters of a Group of Birmingham Pupil Teachers" (ibid., 1895, p. 97); "Note on a Roman Pottery near Mancetter" (Proc. Soc. Antiq., vol. xvi., p. 404); "On the Prehistoric Implements of Warwickshire and Worcestershire" (Birm. Arch. Soc. Proc., 1897); "Life in Early Britain : being an Account of the Early Inhabitants of this Island and the Memorials which they have left behind them" (London: D. Nutt, 1897).

\section{WORK OF THE SMITHSONIAN INSTITUTION} IN I $897-8$.

THE report of Prof. S. P. Langley, Secretary of the Smithsonian Institution, upon the operations of the Institution for the year ending June 30,1898 , reached us a

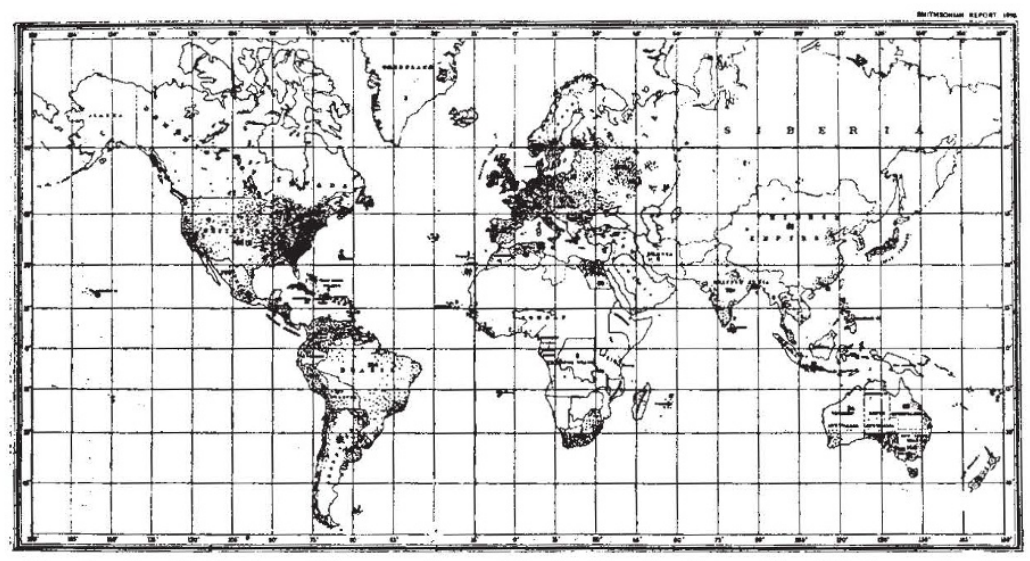

Map showing distribution of Correspondents of the Smithsonian International Exchange Service.

few weeks ago. It refers to the work of the U.S. National Museum, the Bureau of American Ethnology, the International Exchanges, the National Zoological Park, and the Astrophysical Observatory, all of which are under the direction of the Institution.

The promotion of original research has always been one of the principal functions of the Institution. Investigations in the anthropological, biological and geological divisions of science have been extensively carried on through the departments of the National Museum, and in the Bureau of American Ethnology there have also been special inquiries into Indian customs and languages. These lines of research being well represented by its bureaus, it has remained for the Institution proper to devote its energies more especially to some of the physical sciences.

Prof. Langley has carried on researches in the solar spectrum, which, by the active assistance of Mr. C. G. Abbot, have produced important results shortly to be published. He has not wholly discontinued the studies No. I 54 I, voL. 6o] which he has made in regard to aërodromic experiments, and it is perhaps not improper that he should state that these have attracted the attention of other departments so far that during the war with Spain a commission was directed by the Secretaries of War and the Navy to inquire into them with a view of their possible utility in war.

In connection with the Hodgkins fund, several grants have been made for scientific investigations. Mr. A. Lawrence Rotch, of the Blue Hill Meteorological Observatory, Readville, Mass., has received grants for experiments with automatic kites, for determining, by means of self-recording instruments, meteorological data in atmospheric strata inaccessible except by some mechanical method of exploring the atmosphere.

A grant of 500 dollars has been made to Prof. William Hallock, of Columbia University, for an investigation having for its object the complete analysis of a particle of air under the influence of articulate sounds.

A final grant of 250 dollars has been made to Drs. Lummer and Pringsheim, of the Physical Institute of the University of Berlin. The investigation begun by them, in 1893 , to determine the ratio of the specific heats, at constant pressure and volume, for air, oxygen, carbon dioxide and hydrogen has now so far progressed that the memoir submitted by Drs. Lummer and Pringsheim, noting the results already attained by them, has been published by the Institution in the Smithsonian "Contributions to Knowledge."

An additional grant has been made to Mr. E. C. C. Baly, of University College, London, to enable him to continue his research upon the decomposition of the atmosphere by electricity and upon the ozonising of mercury.

A grant of 250 dollars has been made to Prof. Arthur G. Webster, of Clark University, Worcester, Mass., for the continuation of a research on the properties of air in connection with the propagation of sound, special effort being directed to the securing of data relating to the influence of the viscosity of air on expiring or vanishing sounds. An instrument devised by Prof. Webster for use in this investigation gives the physical measure of sound, not only when constant, but when rapidly varying. It is expected that this research will furnish results of high practical value in connection with the question of the acoustics of auditoriums, and will contribute information upon points that have not heretofore been satisfactorily investigated.

The operations of the International Exchange Service continue to extend. In 1887 this branch of the Institution sent out 7I tons of documents, and had 2165 correspondents in the United States and 7396 foreign correspondents; during the year covered by the present report it transmitted $15 \mathrm{I}$ tons, and had 6915 correspondents at home and 22,543 abroad distributed among 93 countries.

Of the total number-29,458 - of correspondents, 12,698 are libraries and 16,760 are individuals. There is no part of the Smithsonian Institution which more efficiently carries out the large purpose of its founder, to diffuse knowledge among men, and it is through this, as much as through any other branch, that its name is known throughout the world.

Appended to the report is a map of the world, a reduction of which accompanies this summary, showing the distribution of the correspondents of the Exchange Service. 